\section{Spraying controversy revived}

A link is suspected between the use of certain tree sprays and the condition known as Reye's syndrome. David Spurgeon reports from Ottawa

THE spraying of forests in the Maritime provinces to prevent infestation by the spruce budworm has created a sharper controversy than ever this spring because of the deaths of five children from a disease suspected of being linked to the insecticides used. It is not the first time arguments have arisen over the spraying programme: DDT was used as an insecticide in the $1950 \mathrm{~s}$ and 1960s until it was found to have caused severe fish kills in surface waters. But it is the first time human deaths have been linked to the programme.

A number of children, mostly from areas that have been heavily sprayed in the past, have died from Reye's syndrome, a condition first described in 1963 following the US Air Force's aerial defoliation in Vietnam and Thailand. The disease causes increased susceptibility to viral infection, and it is the spray dispersal emulsifiers which are suspect; the sprays used are Fenitrothion and Phospamidon.

The current budworm outbreak, which now covers about a third of the province of Nova Scotia, was first reported in 1969. The budworm (Choristoneura fumiferana) is a moth that lays its eggs in firs and spruces in July. The eggs hatch in about 10 days, and the larvae spread through the trees.

\section{Canadian cutbacks}

THE Royal Society of Canada has joined in the general clamour of protest by Canadian scientists against a federal frecze on research funds. The Prime Minister, M Pierre Trudeau, recently received a brief signed by $\mathrm{W}$. Bennett Lewis, president of the council of the Society's Academy of Science, which said the 1975-76 level of federal support for government laboratories was only $83.3 \%$ of the 1969 level in terms of the fraction of federal budgetary expenditures. Research in Canadian universitics is in an even worse position, with support in 1975 reduced to $67 \%$ of the 1969 level-and although the decline was arrested last year, the freezing of grants this year will cause support to decline to about $60 \%$ of the 1969 level.

Although it was recognised in 1969
They remain dormant for the winter, emerging in late April and early May to begin feeding on new shoots. In June they enter the pupal stage, and the moths which emerge in June or July can defoliate and kill trees to the extent of causing their death.

Massive increases in population can occur when there is a large incidence of host trees and favourable weather. This has happened in the Maritime provinces six times since the early 1700 s. Predictions for this year were bad from the point of view of the forest industries, particularly in Cape Breton Island, so Novia Scotia Pulp Ltd and Nova Scotia Forest Industries-a branch of Stora Kopparbergs Bergslags AB of Sweden-applied to the Nova Scotia government for permission to spray with Fentrothion or Phospamidon.

The Nova Scotia department of lands and forests recommended against it, but the Cabinet gave approval in February. Seven weeks later, on April 2, Cabinet approval was withdrawn as a result of a story that appeared first in the Cape Breton Post and subsequently in other newspapers. The story summarised the work of a research team at Dalhousie University begun in 1974 which indicated that a link was possible between the spraying programme and the deaths from Reye's syndrome. It was based on material given to the Post's editor by a PhD student who was a member of an environmentalist group.

The research group had published a

that government support of industrial research and development was already too small, it is now even smaller, the brief said. In terms of the fraction of federal budgetary expenditures it had fallen by 1975 to $68 \%$ of the 1969 level. To make matters worse, the Department of Industry, Trade and Commerce had abolished one of its aid-to-industry research and development programmes and had cut back another.

Tables and graphs accompanying the brief showed that Canada was alone among advanced nations in its reductions in support for science and technology. Organisation in other industrialised countries with functions similar to those of the National Research Council of Canada (supporting in-house research and development and university grants and scholarships) had been treated almost as well, and in some cases better, than they were in 1969. preliminary report on their work in The Lancet in 1974, and has a further paper in press now. Its members applied spray chemicals topically to the abdomens of about 13,000 mice in the same concentrations used in the spraying programme, and then exposed the animals to a virus. They found that the mice died, not as a result of the virus or of toxin but of some third entity. At the time they published in 1974, they had applied only the insecticides as sprayed, to the animals. Later they purchased the carrier substances separately and concluded that one of the emulsifiers used in the sprays was probably the substance linked to Reye's syndrome.

Dr J. F. S. Crocker, one of the research group and an assistant professor of paediatrics, emphasises that the research has been strictly with animals and indicates only that a link between the spraying programme and the deaths from Reye's syndrome "is possible theoretically." The group is now planning in vitro experiments and work with primates, and has proposed identifying chemicals in the tissues of children struck by Reye's syndromeif possible before they succumb. Dr Crocker himself finds it extraordinary that so little research has been done in this field. He says that if the companies that do the spraying make up their own spray formulation, they do not even require a licence for the emulsifiers, whereas the spray mixture must be licenced if it is packaged as a readymade formulation. Yet the chemical structure of the emulsifiers is unknown - and of course the effects on humans are unknown.

The budworm problem has been worst in New Brunswick in past years, and has only recently spread to Nova Scotia. No spraying has actually been carried out in Nova Scotia, but in New Brunswick it has always been carried out by Forest Protection Ltd, a Crown corporation representing the provinces and its major pulp and paper industries. Decisions about whether to spray or not in a given area have been made by the corporation's board of directors and approved by federal and provincial governments. Costs have been shared equally by the federal government, provincial government and industry. Fenitrothion has been the chief insecticide used since 1968: it is claimed to be non-persistent, non-cumulative and not subject to concentration in the food chain. There is also evidence it is less harmful to fish than is DDT.

This year's spraying programme in New Brunswick will cover 10.2 million acres. The federal government has opted out of the programme, but the federal department of regional eco- 